ARID International Journal for Science and Technology (AIJST)

ISSN: 2662-009X

Journal home page: http://arid.my/j/aijst
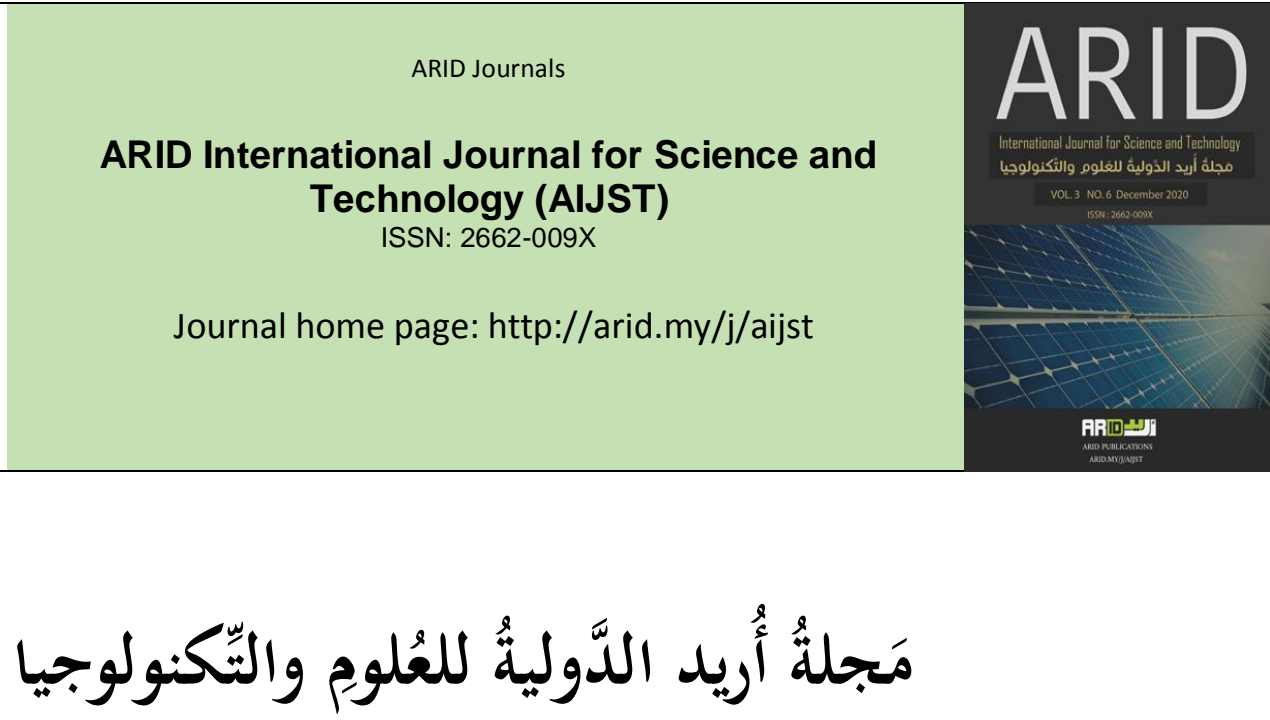

العدد 6 ، البحلد 3 ، كانون الأول 2020 م

\title{
Genotyping of Acinetobacter baumannii that isolate from different cases by using ERIC
}

\author{
Rana Mujahid Abdullah
}

Rasha Zaid Tariq Ahmed

Department of Biology, College of Education Ibn-Al Haitham, University of Baghdad.

\author{
التنميط الجيني دـ Acinetobacter baumannii المعزولة من حالات سريرية مختلفة \\ ERIC باستخدام \\ رشازياد طارق \\ رنا مجاهد عبدالها \\ قسم علوم الحياة / كلية التربية للعلوم الصرفه ابن الهيثم / جامعه بغداد / بغداد ـ العراق
}




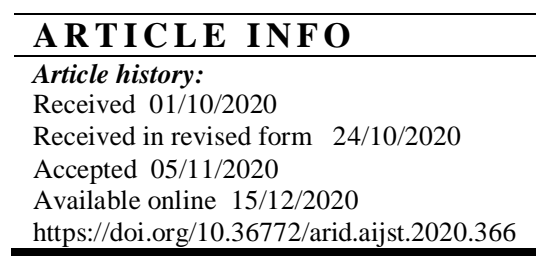

\begin{abstract}
Determination of genetic relatedness typing between isolates has done for Acinetobacter baumannii isolates by using Enterobacterial Repetitive Intergenic Consensus-PCR (ERIC-PCR), the results of the current study showed the presence of a genetic relationship between bacterial isolates isolated from different clinical sources. The results of the study showed the presence of 18 patterns, the molecular weight of these bands ranged between (100-4000) bp.

Dendogram analysis of the results showed that there was genetic relatedness between the isolates of Acinetobacter baumannii in only one clone while 37 isolated contain different genotyping.
\end{abstract}

Key words: Acinetobacter baumannii, ERIC, Genotyping. 


\section{الخلاصة}

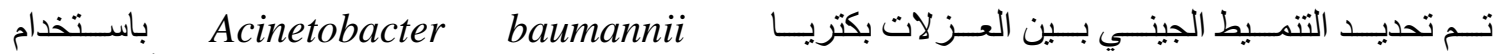
Enterobacterial Repetitive Intergenic Consensus-PCR (ERIC-PCR)

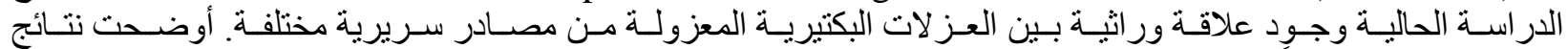

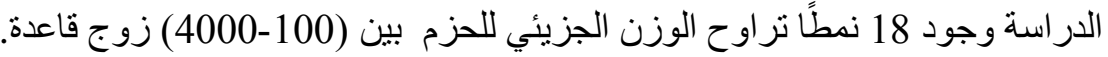

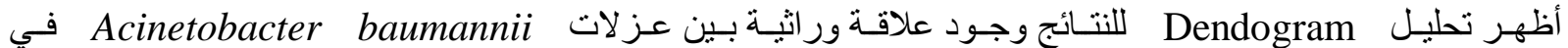
نسيلة واحدة فقط بينما احتوت 37 معزولة على أنماط ور اثية مختلفة.

الكلمات المفتاحية :- ERIC ، Acinetobacter baumannii ، التنميط الجيني. 


\section{Introduction}

Genotyping distinguishes between bacterial isolates on their genetic content. There are several methods for genotyping that have become important in the field of finding genetic relatedness between bacterial isolates, identifies the source of infection and works to identify strains of high virulence to prevent infection, especially in intensive care units that are a place for the emergence of many antibiotic resistance bacteria [1].

There are several methods of genotyping that used in present time that different in its ability to distinguish between the bacterial isolates in the same species. One of these methods is Restriction Fragment Length Polymorphism (RFLP), the method of gel electrophoresis with a pulsed field Electrophoresis, Repetitive Sequence-PCR [2, 3]. This method easy and fast methods that do not need time to accomplish, compared to other methods. One of the benefits of this method is the ability to find the genetic affinity for bacterial isolates of the same species $[4,5]$.

The most important types of methods of repeated sequences that was easy, fast, less expensive and less complicated in analyzing the results was Enterobacterial Repetitive Intergenic Consensus (ERIC) method. The sequences of this method were originally discovered in Escherichia coli and Klebsiella pneumoniae [6]. This methods are across multiple regions of the genome and the length of sequences was $126 \mathrm{bp}$. and the location sequences are different from one strain to another and this method has been increasingly used to identify the genetic related relationship of bacteria $[7,8]$.

ERIC method is used between bacterial strains and epidemiological studies, as well as to classify many gram negative bacterial [9]. It has shown a high efficiency to determine the epidemiological range of A. baumannii bacteria [10]. Another study mentioned that this method is one of the best and most accurate methods for 
determining the genetic affinity in A. baumannii [11] and in a study of $A$. baumannii that showed this method is useful to determining the epidemiological and studying the diversity between isolates. Isolates were divided into several groups by this technique [12], as shown in Studies that A. baumannii isolated have resistance genes from several hospitals in Korea can be identified by ERIC-PCR technique. It has been observed that there are 7 isolates that possess a gene resistance anti-beta-complement OXA-23 and 6 isolates that produce an OXA-23 resistance gene from the same hospital [13].

Amis of this study Genotyping of A. baumannii isolates using the Enterobacterial Repetitive Intergenic Consensus (ERIC) method.

\section{Material and methods}

\section{1: Isolates of bacteria}

Were obtained from a previous study of various clinical sources (blood sample, wounds infection, burns infection, urinary tract infections, and stool sample).

\section{2: DNA extracted of DNA}

DNA kit (Geneaid Biotech kit system, UK) was used to extract the DNA of bacterial isolates according to the manufacturer's instructions.

\section{3: Genotyping of A. baumannii using ERIC method}

The polymerase chain reaction mixture was prepared using ERIC method.The proliferation of the ERIC gene with specific primer Prepare the solutions of the Stock according to the instructions of the manufacturer Alpha DNA (Canada) (F: ATGTAAGCTCCTGGGGATTCAC3') and (R: 5' AAGTAAGTAAGTGACTGGGGG TGA GCG 3'). The solution concentration of $10 \mathrm{P}$ mol / $\mu$ l keep the stock solution under $-20^{\circ} \mathrm{C}$. The amplification of DNA was performed at a volume of $20 \mu \mathrm{l}$. The 
reaction mixture is a component of $10 \mu \mathrm{l} \mathrm{GO}$ Taq green master mix, $1 \mu \mathrm{l}$ F-primer, $1 \mu \mathrm{l}$ R-primer, $2 \mu \mathrm{l}$ template DNA, and $6 \mu 1$ Nuclease Deionized nuclease-free water [[14]]. Then the contents were mixed using the Vortex mixer and then placed in a PCR. Steps of PCR reaction were step 1 (Only one cycle for 1 minutes at a temperature of $94^{\circ} \mathrm{C}$ for the primary DNA denaturation), step 2 (35 cycle included: A: $45 \mathrm{sec}$ at $94^{\circ} \mathrm{C}$ for DNA template denaturation, $\mathrm{B}: 45 \mathrm{sec}$ at $94^{\circ} \mathrm{C}$ for the primers to bind to DNA template annealing, C: 2 minute at $48^{\circ} \mathrm{C}$ for the associated primers to be elongated. Step3 (Only one cycle for 10 minute at $72^{\circ} \mathrm{C}$ for the final elongation of the double DNA strip.

\section{4: Separation of DNA bands}

Five $\mu \mathrm{l}$ of PCR products were separated on a $2 \%$ agarose with $5 \mu$ Ethidium bromide, at 100 vol. for $80 \mathrm{~min}$. DNA Ladder 100bp. The DNA bands were visualized and photographed under UV light at 300 nanometer by using UV-tansilluminator [15]. Measuring DNA Concentration with a Florometer quantus.

\section{5: Dendogram synthesis to determine the genetic affinity of A. baumannii isolates}

A synthesis dindogram was found to determine the genetic affinity between the isolates of A.baumannii by converting the results that appeared in the gel into a descriptive table, as when a package is present, 1 is placed and when it is absent, 0 is placed and this data is entered into the Past Software Jaccard / up GMA program to obtain the Dendogram. The molecular weights of the resulting beams were determined using the Cs Analyzer program.

\section{Results and discussion}

Genetic typing was found and identified by Pattern $A$. baumannii under study by using (ERIC) method, the results showed the presence of a genetic relationship between bacterial isolates. The results of the study showed the presence of 18 group 
(ERIC1 to ERIC18) using Past Jaccard / up GMA program, the molecular weight of these bands ranged between (100-4000) bp and the Percentage ranged (5-60)\% as shown in Figure (1 (A and B) ) Table (1) and this result corresponds to the result obtained by [13] with 17 patterns using the ERIC method to standardize the isolates of Acinetobacter from several hospitals in Brazil, and the results in Figure (2) showed the presence of 37 isolates contain different genotypes, While only one clusters contained three isolates which are $(32,35,37)$, there was a genetic affinity between them. These isolates were isolated from patients at Yarmouk Teaching Hospital and the source from which these isolates were isolated was from stool Our results were close to the study by [11] who found a genetic affinity between the isolates of A. baumannii isolated from several hospitals in Turkey and from different sources who showed that using the ERIC-PCR method there was a genetic affinity between three groups of $A$. baumannii isolates. In the study by [10] showed that there were 18 types of $A$. baumannii isolates that were isolated from ICU intensive care units and from several hospitals in Lebanon using the ERIC-PCR method. There was a genetic convergence between four groups of A. baumannii isolates. The researchers showed [16] using the ERIC-PCR method and a genetic affinity between four groups of A. baumannii isolates isolated from ICUs and researchers [17] four groups were found between isolates of A. baumannii using ERICPCR technique isolated from different sources and from several hospitals in China. 


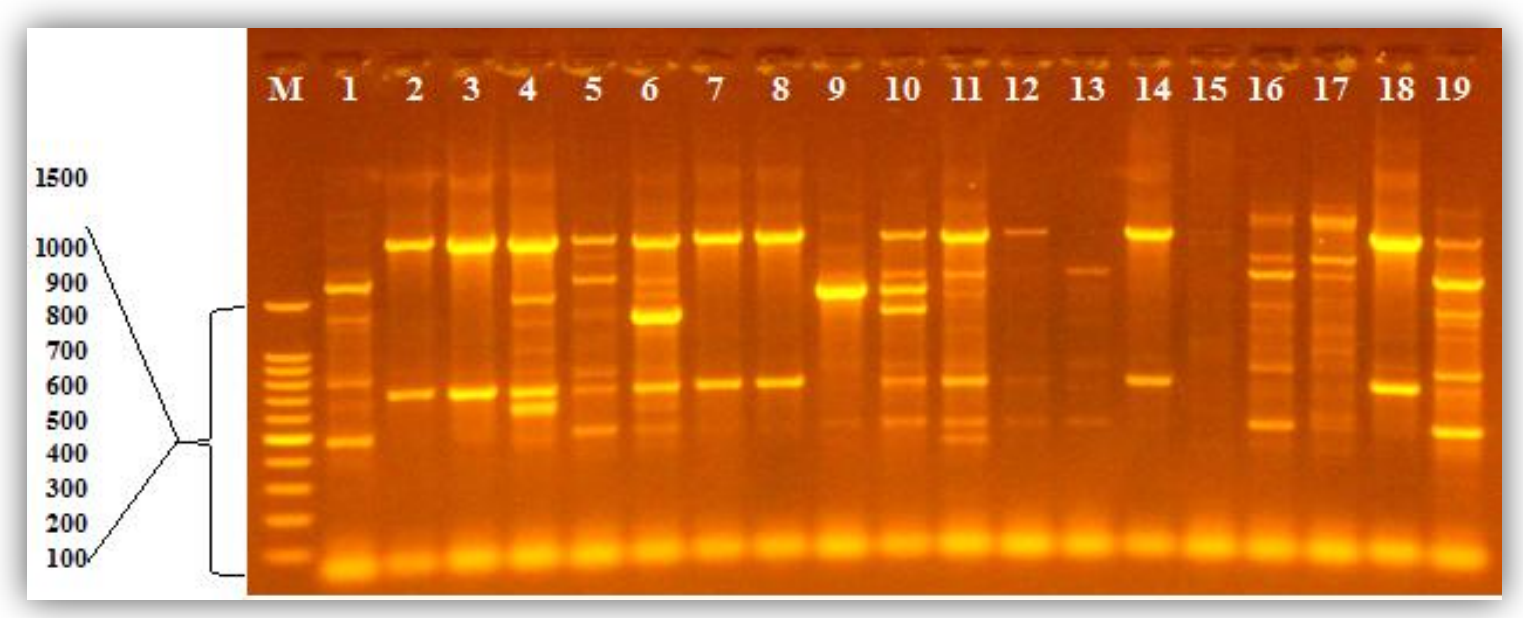

Figure (1-A): Electrophoresis of the PCR product of gene ERIC (100-1500 bp) for $A$. baumanniii isolates on $2 \%$ agarose and 100 volts for $80 \mathrm{~min}$. The M ladder (100 bp), the 1-19 was positive isolates. The molecular weights of the resulting beams were determined using the CS Analyzer 3 program.

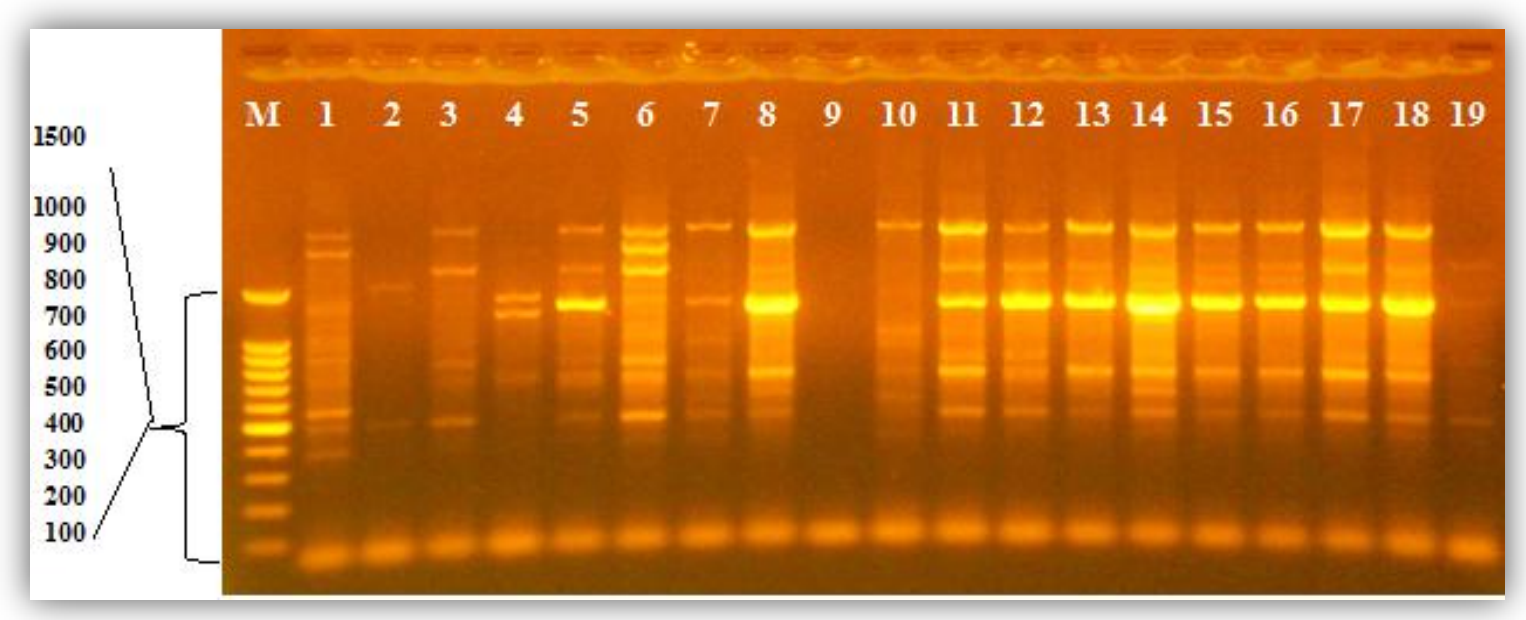

Figure (1-B): Electrophoresis of the PCR product of gene ERIC (100-1500 bp) for A. baumanniii isolates on $2 \%$ agarose and 100 volts for $80 \mathrm{~min}$. The M ladder (100 bp), the 20-38 was positive isolates. The molecular weights of the resulting beams were determined using the CS Analyzer 3 program. 
Table (1): Molecular weights and percentages of the resultant band by ERIC method

\begin{tabular}{|c|c|c|c|}
\hline Bands & $\begin{array}{rr}\text { Molecular } & \text { weight } \\
\text { bp }\end{array}$ & $\begin{array}{c}\text { Isolates } \\
\text { no. }\end{array}$ & $\begin{array}{r}\text { Percentage } \\
\%\end{array}$ \\
\hline ERIC1 & 100 & 8 & 20 \\
\hline ERIC2 & 150 & 9 & 22.5 \\
\hline ERIC3 & 200 & 2 & 5 \\
\hline ERIC4 & 300 & 3 & 7.5 \\
\hline ERIC5 & 400 & 3 & 7.5 \\
\hline ERIC6 & 500 & 5 & 12.5 \\
\hline ERIC7 & 600 & 18 & 45 \\
\hline ERIC8 & 700 & 4 & 10 \\
\hline ERIC9 & 800 & 9 & 22.5 \\
\hline ERIC10 & 850 & 3 & 7.5 \\
\hline ERIC11 & 900 & 15 & 37.5 \\
\hline ERIC12 & 1000 & 13 & 32.5 \\
\hline ERIC13 & 1500 & 17 & 42.5 \\
\hline ERIC14 & 2000 & 23 & 57.5 \\
\hline ERIC15 & 2500 & 7 & 17.5 \\
\hline ERIC16 & 3000 & 24 & 60 \\
\hline ERIC17 & 3500 & 11 & 27.5 \\
\hline ERIC18 & 4000 & 4 & 10 \\
\hline
\end{tabular}




\section{Similarity}

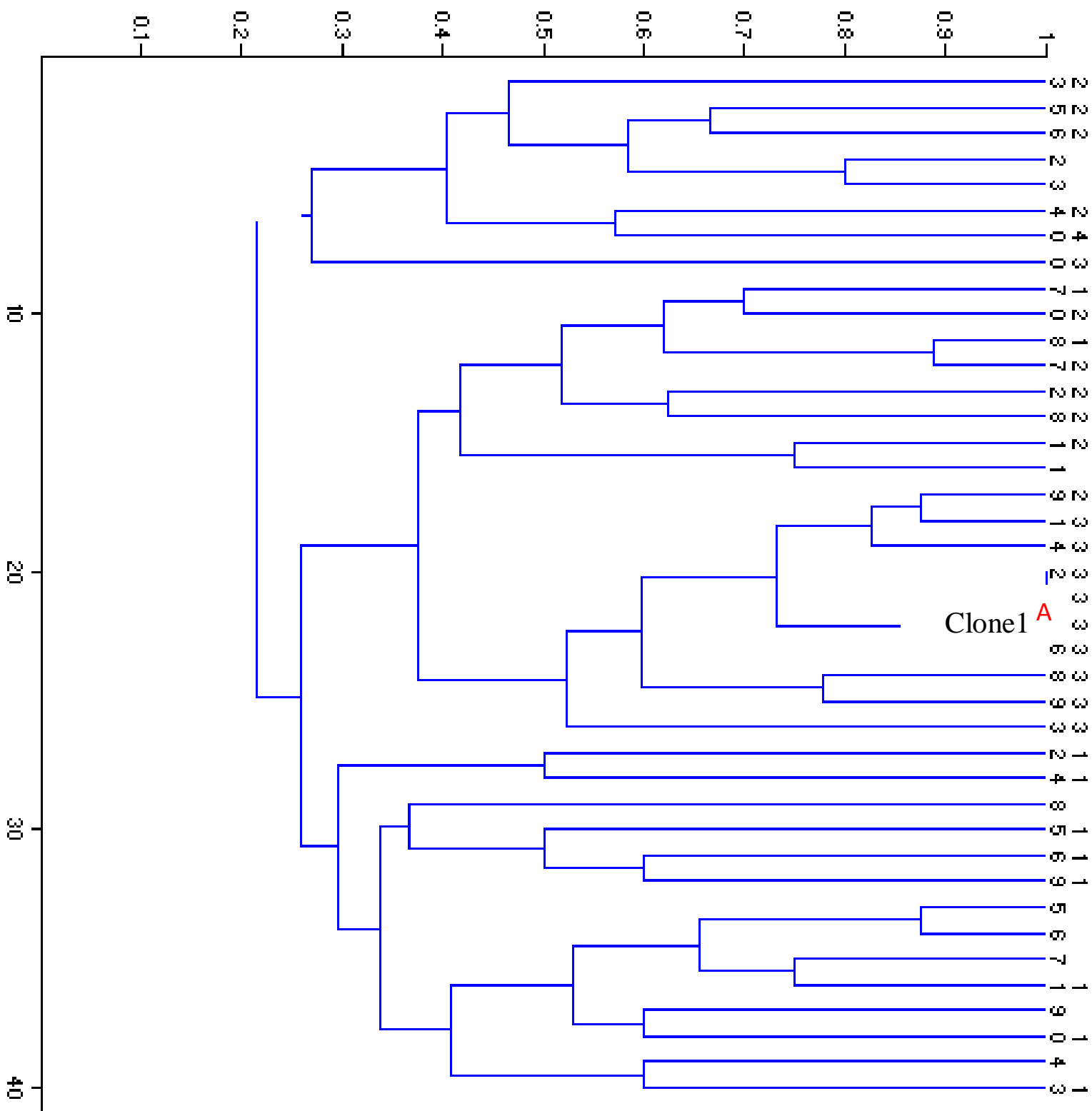

Figure (2): Dendrogram Synthesis of A. baumannii isolates using Past Jaccard / up GMA program. 


\section{Conclusions}

ERIC method has shown high efficiency in determining the genetic and epidemiological relationship between A. baumannii isolates.

\section{Abbreviations}

\begin{tabular}{|l|l|}
\hline Abbreviation & Meaning \\
\hline A. baumannii & Acinetobacter baumannii \\
\hline API20E & Analytical Profile Index \\
\hline bp & base pair \\
\hline DNA & Deoxyribonucleic acid \\
\hline ERIC & Enterobacterial Repetitive Intergenic Consensus \\
\hline RFLP & Restriction Fragment Length Polymorphism \\
\hline NCBI & National Center for Biotechnology Information \\
\hline PCR & Polymerase chain Reaction \\
\hline U.V. & Ultra Violate \\
\hline
\end{tabular}




\section{References:}

[1] I. H. Yildirim, S.C. Yildirim, N. Kocak,"Molecular methods for bacterial genotyping and analyzed gene regions", Journal of Microbiology and Infectious diseases. 1(1) (2011) 42-46.

[2] B. Foxman, L. Zhang, J.S. Koopman, S.D. Manning, C.F. Marrs, "Choosing an appropriate bacterial typing technique for epidemiologic studies", Epidemiologic Perspectives Innovations. 2 (10) (2005)1-8.

[3] H. S.Martins, M.R. Bomfim, R.O. Franca, L.M. Farias, M. A. Carvalho, J.C. Serufo, et al. "Resistance markers and genetic diversity in Acinetobacter baumannii strains recovered from nosocomial bloods stream infections", International Journal of Environ Research Public Health. 11(2) (2014) 1465-78.

[4] R. M. Abdullah, , R. Z. T. Ahmed, S. N. A. Al-Azzawi " Genotyping of Acinetobacter baumannii by using BOX Method", Indian Journal of Forensic Medicine and Toxicology , 13(4)(2019) 934-938

[5] A. Doleans-Jordheim, B. Cournoyer, E. Bergeron, J. Croize, H. Salord, J. Andre, M. Mazoyer, F. Renaud, J. Freney," Reliability of Pseudomonas aeruginosa semiautomated rep-pcr genotyping in various epidemiological situations", Journal of Clinical Microbiology Infectious. 28(9) (2009) 1105-1111.

[6] S.H. Jeong, I.K. Bae, K.O. Park, Y.J. An, S.G. Sohn, S. J. Jang, K.H. Sung, K. S. Yang, K. Lee, D. Young, S.H. Lee, "Outbreaks of imipenem- resistant Acinetobacter baumannii producing carbapenemases in Korea", Journal of Microbiology Seoul, Korea. 44(4) (2006)423-431.

[7] F. Al-Zahraa, M. Gomaa, Z.H. Helal, "Phenotypic Characterization and ERIC-PCR Typing of MDR Acinetobacter species in Egypt", Egyptian Journal of Medical Microbiology. 20(1) (2011). 1-5.

[8] H. Goudarzi, F. Karimi, F. A. Amoli, Z. Abedinyfar, F. Doustdar, F. Mehrnejad, "Genetic fingerprinting and antimicrobial susceptibility profiles of Pseudomonas aeruginosa isolates from eye infections", Journal of clinical infection diseases. 6(1) (2011)41-46.

[9] A. F. Mehdi, "Study of Genotyping and some virulence factor of Pseudomonas aeruginosa", Master Thesis, College of Education for pure science, University of Baghdad, (2015) 4-20.

[10] D. Hammoudi, D. Ayoub, C. Moubareck, N. Hakime, M. Houmani, H. Barakat, Z. Najjar, M. Suleiman, N. Fayad, R. Sarraf, D. Karam- Sarkis, International Journal of Infectious Diseases. 36 (2015) 56-6.

[11] G. Ece, B. Erac, H.Y. Cetin, C. Ece, A. Baysak, " Antimicrobial Susceptibility and Clone Relation between Acinetobacter baumannii Strains at a Tertiary care center in Turkey", Microbiology 8(2) (2015).e15612:1-5.

[12] M. Fouad, A. S. Attia, W.M. Tawakkol, A. Hashem, "Emergence of Carbapenemresistant Acinetobacter baumannii harboring the OXA-23 carbapenemase in intensive care unit of Egyptian hospitals", International Journal of Infectious Diseases. 11 (2013). e1252-4.

[13] A.E. Ferreira, D.P. Marchetti, G.R. da Cunha, L.M. de Oliveira, D. B. Fuentefria, A.G. Dall Bello, G. Corcao, "Molecular characterization of clinical multi resistant isolates of Acinetobacter sp. from hospitals in Porto Alleger, State of Rio Grande do Sul, Brazil", Revista da Sociedade Brasileira de Medicine Tropical. 44 (2011) 725-730. 
[14] S.A. Mansour, O. Eldaly, A. Jiman-Fatani, M.L. Mohamed, E.M. Ibrahim, "Epidemiological characterization of Pseudomonas aeruginosa isolates of intensive care units in Egypt and Saud Arabia ", Eastern Mediterranean Health Journal. 19(1) (2013) 71-80.

[15] J. Sambrook, D. Russell, "Molecular Cloning Laboratory Manual", $3^{\text {rd }}$ ed. Cold Spring Harbor, New York. USA. (2001).

[16] J.C. Medina-presentado, V. Seija, R. Viognoli, J. Pontet, L. Robino, N. F. Cordeiro, I. Bado, G. Fulgueriras, M. Bero, C. Bazet, E. Savio, G. Reppi, "Polyclonal endemicity of Acinetobacter baumannii in Ventilated Patient in an intensive care unit in Uruguay", International Journal of Infectious Diseases. (2013)17. e422- e427.

[17] X, He, F. Lu, F. Yuan, D. Jiang, J. A. Zhu, H. Cheng, J. Cao, C.G. Lua, "Biofilm Formation Caused by Clinical Acinetobacter baumannii isolates Associated with Overexpression of the AdeFGH Efflux Pump", Antimicrobial Agents and Chemotherapy. 59 (8) (2015). 4817-4825. 